\title{
The synergistic use of plant and isolated bacteria to clean up polycyclic aromatic hydrocarbons from contaminated soil
}

\author{
S. Eskandary, A. Tahmourespour, M. Hoodaji and A. Abdollahi
}

\begin{abstract}
Background: Biological methods of polycyclic aromatic hydrocarbons (PAH) contamination elimination typically involve the transformation of contaminants to non-toxic materials by microorganisms and plants and appear to be the most effective methods available.

Methods: In this study, Bacillus licheniformis and Bacillus mojavensis isolated from oil-contaminated soils were inoculated onto Festuca arundinacea seeds before planting in the pot and 3 weeks after planting by syringe injection into the rhizospheric zone in order to study the elimination of PAHs from Festuca's rhizosphere in the greenhouse. Some physical and chemical properties of the soil, PAH concentrations, seeds germination percentage, root and shoot biomasses of the treated samples were examined.

Results: The results showed that the treated samples inoculated with both bacteria had a significantly higher percentage of seed germination and root and shoot biomass compared to other treatments. The concentration of some PAHs reduced significantly (Pvalue $<0.05$ ) in the rhizosphere of the treated samples inoculated with both bacteria compared to in contaminated soils. Concentrations of some PAHs (eg. Naphthalene, Phenanthrene, Benzo[a]anthracene and Dibenzo[a,h]anthracene) even reached below the detection limit of the method. The PAHs concentrations in the treated samples inoculated with bacteria was decreased significantly (Pvalue $<0.05$ ). Therefore, the results showed the high efficiency of the Festuca and bacterial inoculation in eliminating PAHs from the soil.
\end{abstract}

Conclusion: According to the results, the partnership of Festuca with B. licheniformis and B. mojavensis isolates displayed positive effect on PAHs dissipation and can be effective cleanup technology with high performance.

Keywords: Soil Pollution, Phytoremediation, Rhizosphere, Bacteria, PAH

\section{Background}

PAHs are aromatic compounds with two or more benzene rings. They are usually produced by the thermal decomposition of organic molecules and similar compounds [1]. The common sources of these compounds in the environment might be human activities, wildfire, oil spills and volcanoes. These compounds are known as toxic, mutagenic and carcinogenic pollutants [2] and can not easily eliminate from the environment under natural conditions; and as their molecular weight increases, their resistance to degradation also increases. Due to their widespread presence in the air, soil and sediments, they

\footnotetext{
* Correspondence: atahmoures@khuisf.ac.ir; a.tahmoures.p@gmail.com

Isfahan(Khorasgan) Branch, Islamic Azad University, Arghavanieh Bv, Jey street, Isfahan, Iran
}

(c) The Author(s). 2017 Open Access This article is distributed under the terms of the Creative Commons Attribution 4.0 International License (http://creativecommons.org/licenses/by/4.0/), which permits unrestricted use, distribution, and reproduction in any medium, provided you give appropriate credit to the original author(s) and the source, provide a link to the Creative Commons license, and indicate if changes were made. The Creative Commons Public Domain Dedication waiver (http://creativecommons.org/publicdomain/zero/1.0/) applies to the data made available in this article, unless otherwise stated.

have attracted a lot of attentions in different studies. These compounds should be eliminated from the environment because evidences indicate that PAHs mixtures are teratogenic, mutagenic and carcinogenic to humans [3]. Different methods such as biological, thermal, physical, chemical and solidification can be applied for soil remediation [4]. Among the different methods of remediation, biological techniques are often regarded as cost - effective and environmental friendly [5].

Bioremediation is the productive utilization of living systems to degrade, detoxify, transform, immobilize or stabilize toxic environmental contaminants which require the least amount of energy and chemical substance. One of the bioremediation strategies is phytoremediation which is the use of plants for contaminant removal from 
the soil. Phytoremediation makes use of advantages such as the plants' complex root system, which occupies a large body of the soil. The root system also protects a large population of bacteria in the rhizosphere and produces secretions that can directly impact the activity of the bacterial population present in the rhizosphere and eliminate contamination. Plants used for this purpose should have more flexibility and compatibility in stress conditions caused by the presence of hydrocarbons [6]. The symbiotic relationship between plants, microorganisms and the environment is one of the new methods for cleaning oilcontaminated soils. So, it is believed that isolation of indigenous bacteria with the ability to degrade PAHs and their addition to the rhizosphere of plants (such as Festuca) can improve the remediation efficacy. Extensive attention has been paid on PAHs degradation by gram-negative bacteria, but, less attention has been intended on the PAHs degradation by gram-positive bacteria of Bacillus species [7] and also their partnership in the rhizosphere of plants as such Festuca.

Doyle [8] has shown that a higher level of PAH degradation occurs close to the plant roots [8]. A study conducted in 2013 by Liu et al. on the effects of oat on the phenanthrene degradation in soil showed that growing oat in soils contaminated with this compound stimulates its degradation. As a result, the concentration of phenanthrene in the cultivated soil after harvest was significantly reduced compared to in non-cultivated soil $(P<$ 0.05). They also stated that oat cultivation stimulates microbial biomass first and ultimately phenanthrene degradation [9]. Although abiotic factors such as $\mathrm{pH}$, moisture, oxygen and available nutrients can affect $\mathrm{PAH}$ degradation, microbial processes have a notably greater share in the degradation of these compounds [10]. Specific populations of decomposing bacteria are absorbed to petroleum hydrocarbons. Also, there is plant-microbe interaction in bioremediation process. However, plants, throughout their 'rhizosphere effects', can support hydrocarbon-degrading bacteria that assist in bioremediation in the root zone [1]. Application of plants in combination with some microorganisms to increase the efficiency of contaminants bioremediation can be valuable [11]. Banks et al. [6] stated that when herbaceous plants are infected with bacteria, they can decompose a wide range of chlorobenzoic acids. A wide range of herbaceous plants and legumes, along with their symbiotic bacteria, have shown to increasingly remove oil contaminations from the soil [6].

Therefore, we hypothesized plants inoculated with indigenous PAHs degrading bacteria may enhance bioremediation efficiency of petroleum contaminated soils in comparison to non-inoculated plants. The objectives of this study were to isolate PAHs degrading bacteria from polluted soil and investigate the effect of Festuca arundinacea inoculated with and without indigenous isolated bacteria (Bacillus licheniformis and Bacillus mojavensis) to clean up PAHs from contaminated soil.

The Festuca was selected due to its relatively fast growth, and that is a natural plant of Iran. Moreover, $F$. arundinacea has been used in several phytoremediation studies on oil contaminated soils without inoculated with such isolated $[6,12]$.

\section{Methods \\ Sampling}

The soil around refinery tanks of oil and gas, which often exposed to contamination by oil and its derivatives, was randomly selected for this study. With the aid of hand trowel, soil samples were collected in plastic bags from ranges $0-30 \mathrm{~cm}$ of the contaminated soil around Esfahan oil and gas refinery in Esfahan province, Iran $\left(32^{\circ} 47^{\prime} 19^{\prime \prime} \mathrm{N}, 51^{\circ} 30^{\prime} 24^{\prime \prime} \mathrm{E}\right)$ and mixed together. The samples $(\sim 50 \mathrm{Kg})$ were then air dried, grounded and passed through $2 \mathrm{~mm}$ sieve and immediately transferred to the laboratory. The soil was used for isolation of PAHs-degrading bacteria (10 gr) and also for bioremediation experiments.

\section{Measurement of physical and chemical properties of the soil}

After transferring the soil samples, their $\mathrm{pH}$, electrical conductivity, and organic matter were measured. The soil $\mathrm{pH}$ was measured in its saturated extract using a $\mathrm{pH}$ meter (model 262, Horiba) calibrated with buffer solutions [13]. The Walkley-Black method was used to measure the soil organic matter (OM). Type of soil texture was defined using a hydrometer and the electrical conductivity (EC) of the saturated extract was determined using a conductivity meter [14].

\section{Screening and identification of PAHs-degrading bacteria} PAHs-degrading bacteria were isolated from contaminated soils using an enrichment culture technique in Basal Salt Medium (BSM) supplemented with $12.8 \mathrm{mg} / \mathrm{L}$ PAHs as sole sources of carbon and energy. The BSM contained per liter: $\mathrm{KH}_{2} \mathrm{PO}_{4}$ of $1.0 \mathrm{~g}, \mathrm{Na}_{2} \mathrm{HPO}_{4} \cdot 12 \mathrm{H}_{2} \mathrm{O}$ of $1.25 \mathrm{~g}$, $\left(\mathrm{NH}_{4}\right)_{2} \mathrm{SO}_{4}$ of $1.0 \mathrm{~g}, \mathrm{MgSO}_{4} .7 \mathrm{H}_{2} \mathrm{O}$ of $0.5 \mathrm{~g}$, $\mathrm{CaCl}_{2} .6 \mathrm{H}_{2} \mathrm{O}$ of $0.05 \mathrm{~g}$, $\mathrm{FeSO}_{4} .7 \mathrm{H}_{2} \mathrm{O}$ of $0.005 \mathrm{~g}$, and $\mathrm{pH}$ of 7.0 ( $\mathrm{pH}$ meter, Metrohm 827). The medium was autoclaved at $121{ }^{\circ} \mathrm{C}$ for $20 \mathrm{~min}$. The PAHs mixture (sigma Aldrich Co.) was filter-sterilized (using $0.22 \mu \mathrm{m}$ pore film) and added at final concentrations of $12.8 \mathrm{mg} / \mathrm{L}$ to the Erlenmeyer. The solvent was allowed to evaporate on a rotary shaker before adding the BSM and soil sample. The amount of $50 \mathrm{ml}$ sterilized BSM was added to the Erlenmeyer flask, and $1 \mathrm{~g}$ of contaminated soil was suspended in it. All cultures and controls (without PAHs) were incubated for 7 days at $30{ }^{\circ} \mathrm{C}$ on a dark 
rotary shaker (Vision $8480 \mathrm{SFN}$ ) at $150 \mathrm{rpm}$. At the end of each week, $10 \%$ of the cultured medium was transferred to the fresh medium. After five consecutive enrichments, $0.5 \mathrm{ml}$ of the last enrichment cultures were spread onto solidified BSM plates (2\% agar) and sprayed with concentrated PAH solutions. The plates were then incubated at $30{ }^{\circ} \mathrm{C}$ and routinely checked for colony growth. Colonies with different morphology were picked and streaked onto fresh nutrient agar plates to obtain pure culture $[15,16]$.

Identification of isolates was performed by morphological and biochemical characteristics [17]. Further identification of isolates was done using the $16 \mathrm{~S}$ rDNA gene amplification by PCR (Thermocycler, Eppendorf 632500) using universal primers $27 \mathrm{~F}$ (5'-AGAGTTTGATCCTGGCTCAG-3') and 1492R (5'-GGTTACCTTGTTACGACTT-3'). Two isolates, Bacillus licheniformis ATHE9 and Bacillus mojavensis ATHE13 with NCBI accession numbers of KC329470 and KC469987 were finally selected and used for seeds inoculation [18].

Inoculation of bacteria into seeds of Festuca arundinacea The seeds were first surface sterilized by soaking in $70 \%$ (v/v) ethanol for $1 \mathrm{~min}$ and rinsed 3 times with sterile distilled water and then they were soaked in 1:10 (v/v) dilution of commercial hypochlorite bleach for $15 \mathrm{~min}$ and rinsed several times with sterilized distilled water [19]. For inocula preparation, the isolated bacteria were grown overnight. Cells were harvested in exponential phase (OD600 0.8) and centrifuged at $3000 \mathrm{rpm}$ for $10 \mathrm{~min}$. The first inoculation of seeds with bacterial cells was done before planting. For this, sterilized seeds were soaked in bacterial cell suspension (cell density $9 \times$ $10^{8} \mathrm{CFU} / \mathrm{ml}$ ) for $30 \mathrm{~min}$. Then; they were planted (without rinsing) in the plastic pots $27 \mathrm{~cm}$ in height and $25 \mathrm{~cm}$ in diameter containing $3 \mathrm{Kg}$ of polluted soil. Further inoculation ( $1 \mathrm{ml}$ with the same concentration) was done three weeks after planting by syringe injection into the rhizospheric soil (For control treatment the same volume of water was injected into the soil). The seeds without bacterial inoculation were used as the control treatment $[20,21]$.

\section{Bioremediation of contaminated soil}

The above plants were cultivated under controlled conditions in a greenhouse for a period of 3 months, during which time they were exposed to sun light for $18 \mathrm{~h}$ daily with a maximum temperature of $30{ }^{\circ} \mathrm{C}$ and a minimum temperature of $20^{\circ} \mathrm{C}$. All the pots were watered based on $75 \%$ of soil field capacity. There was no drainage available that showed no water leaching out of the pots. After that their growth period was completed, the soil around the roots of each treated sample was gently and carefully separated and then transferred to the laboratory for extracting purposes [22]. There were three replicates in each treatment.

\section{Measurement of PAH concentrations}

The present study examined 10 polycyclic aromatic hydrocarbons, that is, Naphthalene, Acenaphthene, Acenaphthylene, Phenanthrene, Chrysene, Anthracene, Benzo[a]anthracene, Benzo[a]pyrene, Dibenzo[a,h]anthracene, Benzo[ghi]perylene. To examine PAH concentrations, $5 \mathrm{~g}$ of soil sample passed through $2 \mathrm{~mm}$ sieve with $5 \mathrm{~g}$ of activated sodium sulfate and a mixture of $150 \mathrm{ml}$ of acetone and dichloromethane with a 1:1 volume ratio and was then extracted using a Soxhlet extractor. After reducing the soil sample volume through a rotary evaporator and drying it with nitrogen gas, it was kept in the freezer at $-20{ }^{\circ} \mathrm{C}$ until injection. At the time of the injection of soil extracts to the Agilent 7890a GC-FID, specific concentrations of an internal standard with m-Terphenyl were added to all the samples [23, 24]. An HP5 column with an internal diameter of 250 micrometers, a length of 30 meters and a thickness of 0.25 micrometers was used to measure the PAHs with the GC-FID. The GC-FID was programmed with an inlet temperature of $260^{\circ} \mathrm{C}$ and a nitrogen carrier gas flow of $1.5 \mathrm{ml}$ per minute. The device's initial temperature started at $70{ }^{\circ} \mathrm{C}$ and reached $290{ }^{\circ} \mathrm{C}$ with a gradient of $5{ }^{\circ} \mathrm{C}$, and then reached $305{ }^{\circ} \mathrm{C}$ with a gradient of $1{ }^{\circ} \mathrm{C}$ per minute. Detector temperature was taken as $270{ }^{\circ} \mathrm{C}$ in this program. Field and laboratory blanks were extracted with each batch of sample to reflect laboratory contamination variability. For a compound to be positive, the sample must have exceeded the method detection limit (MDL), defined as MDL = mean blank + $3 \times \mathrm{SD}$ of the blank. Where there were no peaks in the blanks, the instrumental detection limits (IDLs) were used. The IDL defined as the amount of analyte that generated a signal to noise ratio of three.

\section{Statistical analysis}

The experiment was carried out in a randomized complete block design with three replications. The treatments were designed in the form of Festuca arundinacea inoculated with B. licheniformis ATHE9 $\left(\mathrm{F}_{1}\right)$, Festuca inoculated with B. mojavensis ATHE13 $\left(\mathrm{F}_{8}\right)$, Festuca inoculated with both bacteria $\left(\mathrm{F}_{1,8}\right)$ and Festuca without inoculations $\left(\mathrm{F}_{0}\right)$. Statistical analysis of the experimental data was performed using statistical software known as SAS (Release 9.1). Mean comparisons were done with the Duncan test at a significance level of 0.05 .

\section{Result and Discussion}

\section{Soil properties}

Some physical and chemical properties of the soil were measured, which are presented in Table 1. The availability of nutrients and even contaminants depends on the 
Table 1 Physical and chemical properties of the soil before land remediation

\begin{tabular}{lccccccc}
\hline $\mathrm{pH}$ & $\mathrm{EC}\left(\mathrm{dS} \mathrm{m} \mathrm{m}^{-1}\right)$ & $\mathrm{CEC}\left(\mathrm{meq} 100 \mathrm{~g}^{-1}\right)$ & $\mathrm{OM}(\%)$ & Clay $(\%)$ & Sand (\%) & Silt (\%) & FC water content \%) \\
\hline $7.24 \pm 0.04$ & $3.4 \pm 0.25$ & $7 \pm 1$ & 4.6 & 16.6 & 75 & 8.4 & 22.4 \\
\hline
\end{tabular}

EC Electrical Conductivity, CEC Cation Exchange Capacity, OM Organic Matter, FC Field Capacity

degree of soil acidity. The most suitable $\mathrm{pH}$ for soil microorganism' activity is 7 , as nutrient solubility depends on soil $\mathrm{pH}$ changes [25]. The soil used in the present study has neutral $\mathrm{pH}$ and therefore does not limit the activity of microorganisms or the solubility of nutrients except for phosphorus. According to the results provided in Table 1 and using the soil texture triangle, the type of soil was identified as loamy sand. Since the clay content percentage of this soil is low, the adsorption of hydrocarbons to these particles is also decreased and they become more prone to microbial degradation. Afzal et al. [26] suggest that soil type affects the bacterial colonization and microbial activities and thus the efficiency of contaminant degradation. The highest levels of hydrocarbon degradation were seen in loamy soil in their study [26]. The appropriate content of organic matter in the soil is approximately $5 \%$. In the examined soil, this content was $4.6 \%$, pertaining only to contaminants, as the examined soil lacked vegetation for a long time. The cation exchange capacity is 7 (meq/ $100 \mathrm{~g}^{-1}$ ), which is rather low, and might be attributed to the low clay content of the soil. Lease [27] mentioned that soils physicochemical properties such as organic matter affect organism's ability to establish and achieve degradation in the soil environment significantly [27].

\section{The PAHs concentration in contaminated soil}

The concentrations of PAHs in the soil treatments are listed in Table 2. Results demonstrate that the concentration of these hydrocarbons in soil is much higher than the acceptable range of 50 to $1100 \mu \mathrm{g} / \mathrm{kg}$ [28]. These results are indicative of the high level of contamination in the soil, confirming the necessity of cleansing the soil from hydrocarbons.

\section{Some physiological properties of the plant}

Some of the plant properties such as seed germination percentage, root, and shoot biomass of the treated samples are shown in Figs. 1 and 2. The germination percentage of Festuca in contaminated soil has severely decreased in the treated samples from approximately $85 \%$ in non-contaminated soil (data not shown in Fig. 1) to about $20 \%$ in contaminated soil. As shown in Fig. 1, the treated sample inoculated with both bacteria $\left(\mathrm{F}_{1,8}\right)$ had a higher germination percentage with a significant difference $(\mathrm{p}<0.05)$ compared to other treated samples, thus improved germination conditions in the presence of both bacteria is indicated. It is possible that the presence of hydrocarbons in soil can affect the ability of the soil to provide water and oxygen for the seeds, thus delaying the germination in the presence of hydrocarbons or other toxicities are may be due to preventing water and oxygen infiltrating to the seeds [29]. Increasing the seeds' germination percentage of inoculated plant with both bacteria $\left(\mathrm{F}_{1,8}\right)$ can reflect that, maybe a good amount of water and oxygen infiltrates the seeds and therefore improves their germination percentage. The inoculated bacteria belonged to the Bacillus species which are studied extensively for the production of secondary metabolites and surface active compounds, such

Table 2 Concentration of Heavy $(H)$ and Light $(L)$ polycyclic aromatic hydrocarbons in the soil treatments

\begin{tabular}{|c|c|c|c|c|c|c|}
\hline & \multirow[t]{3}{*}{ Hydrocarbon } & \multicolumn{5}{|c|}{ Concentration $\left(\mathrm{mg} \mathrm{kg}^{-1}\right)$} \\
\hline & & \multirow{2}{*}{$\begin{array}{l}\text { Untreated } \\
\text { soil }\end{array}$} & \multicolumn{4}{|l|}{ Treated soil } \\
\hline & & & $\mathrm{F} 1$ & F8 & $\mathrm{F} 1,8$ & F0 \\
\hline \multirow[t]{5}{*}{ L PAHs (2-3 rings) } & Naphthalene & $16 \pm 6$ & $2.4 \pm 0.3^{b}$ & $N D^{c}$ & $\mathrm{ND}^{c}$ & $12.2 \pm 0.9^{a}$ \\
\hline & Acenaphthene & $18 \pm 4$ & $2.9 \pm 0.14^{b}$ & $1 \pm 0.2^{c}$ & $3.5 \pm 0.7^{\mathrm{b}}$ & $5.7 \pm 1.5^{\mathrm{a}}$ \\
\hline & Acenaphthylene & $32 \pm 9$ & $4.7 \pm 1^{b}$ & $2.2 \pm 0.14^{b}$ & $2.6 \pm 0.5^{b}$ & $5.7 \pm 2^{\mathrm{a}}$ \\
\hline & Anthracene & $4.5 \pm 2$ & $1.5 \pm 0.3^{b}$ & $N D^{b}$ & $1.3 \pm 0.12^{b}$ & $4 \pm 1.2^{\mathrm{a}}$ \\
\hline & Phenanthrene & $6 \pm 2$ & $1.5 \pm 0.4^{b}$ & $N D^{b}$ & $N D^{b}$ & $3.2 \pm 1.25^{\mathrm{a}}$ \\
\hline \multirow[t]{5}{*}{ H PAHs (4-6 rings) } & Benzo[a]anthracene & $22 \pm 8$ & $2.3 \pm 0.3^{b}$ & $N D^{c}$ & $N D^{c}$ & $17 \pm 3.19^{\circ}$ \\
\hline & Benzo[a]pyrene & $5 \pm 1.3$ & $2.6 \pm 0.28^{\mathrm{ab}}$ & $1.7 \pm 0.4^{b}$ & $2.2 \pm 0.5^{\mathrm{ab}}$ & $3.6 \pm 0.55^{a}$ \\
\hline & Benzo[ghi]perylene & $2.5 \pm 1$ & $N D^{b}$ & $2.2 \pm 0.14^{a}$ & $1.6 \pm 0.4^{a}$ & $2.4 \pm 0.15^{\mathrm{a}}$ \\
\hline & Chrysene & $16 \pm 6$ & $3.4 \pm 0.24^{c}$ & $5.1 \pm 0.35^{b}$ & $N D^{d}$ & $16 \pm 3.65^{\mathrm{a}}$ \\
\hline & Dibenzo[a,h]anthracene & $8 \pm 2$ & $3.9 \pm 0.28^{b}$ & $3.9 \pm 0.2^{b}$ & $N D^{c}$ & $6 \pm 1^{a}$ \\
\hline
\end{tabular}

F1: Festuca with B. licheniformis ATHE9, F8: Festuca with B. mojavensis ATHE13, F1,8: Festuca with both bacteria (F1,8) and F0: Festuca without inoculations (control), Means with different letters $\left(a, b\right.$ and $c$ ) are significantly different at $5 \%$ level test. ND: Not detected (below the detection limit (DL) of $\mathrm{method}$ ), DL $=0.03 \pm 0.015 \mathrm{mg} \mathrm{kg}{ }^{-1}$ 


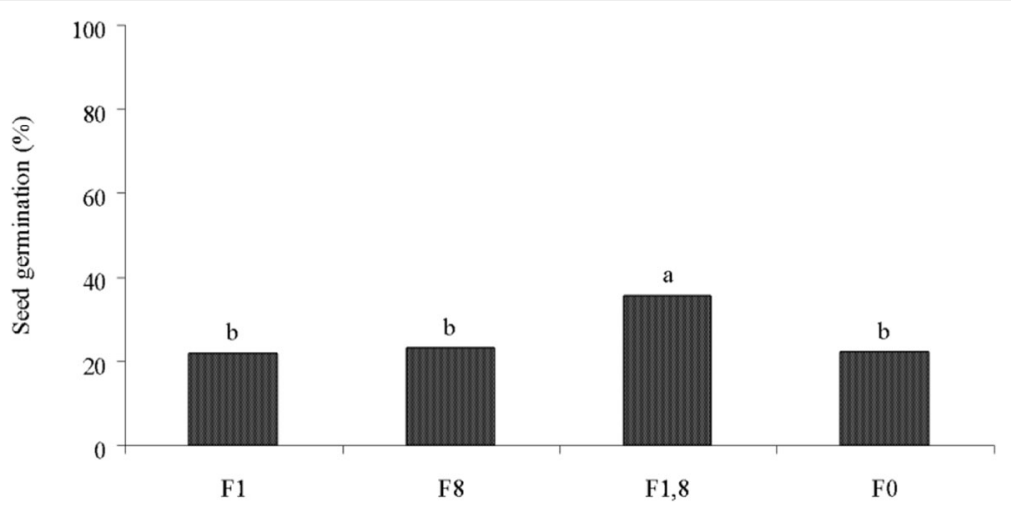

Fig. 1 The percentage of seed germination in the treatments. F1: Festuca with B. licheniformis ATHE9, F8: Festuca with B. mojavensis ATHE13, F1,8: Festuca with both bacteria (F1,8) and F0: Festuca without inoculations (control), Means with different letters $(a, b)$ are significantly different at $5 \%$ level

as surfactin, fengycin, lichenysin, iturin, pumilacidin and bacillomycin. Biosurfactant helps to solubilize or mediate the interaction between the bacterium and the compound [7]. So, Bacillus species are the good choice for bioremediation studies. Jalilzadeh Yengejeh et al. also showed that B. subtilis has the ability of oil hydrocarbons biodegradation and biosurfactant production [30]. Shahidi and colleagues also indicated that Bacillus species can biodegrade crude oil and similar compounds [31].

In the majority of the research conducted on herbaceous plants, rhizospheres are used for the degradation of hydrocarbons. Degradation is facilitated through the effect of rhizosphere; roots of plants secrete organic compounds, increasing the density and activity of potential hydrocarbondegrading bacteria in the area around the roots. Herbaceous plants are therefore chosen for phytoremediation due to their diffuse root system, extensive capillary roots and higher amounts of enzyme production [32].
Festuca plant seeds are more sensitive to contaminated conditions compared to other plant seeds. In a similar study, the germination of Tall Festuca, Red Festuca and Perennial rye-grass was studied in PAH-contaminated soil with a concentration of $5000 \mathrm{mg} / \mathrm{kg}$. The best germination was reported by rye-grass with 2 days of delay while the low germination rate pertained to Red Festuca with 9 of days' delay [33]. Figure 2 presents the root and shoots biomass of Festuca arundinacea plant after treatments. As evident by the figure, the root and shoot biomasses were significantly higher in the plant inoculated with both bacteria $(\mathrm{p}<0.05)$ compared to other treatments. One research has shown that, in contaminated conditions, root and shoot biomasses also decrease as the plant wastes most of its energy adjusting to the contaminated conditions and absorbing water and nutrients from the soil [34]. The results of this study indicate that the inoculation of both bacteria has balanced the hydrocarbon-contaminated conditions of the soil for the

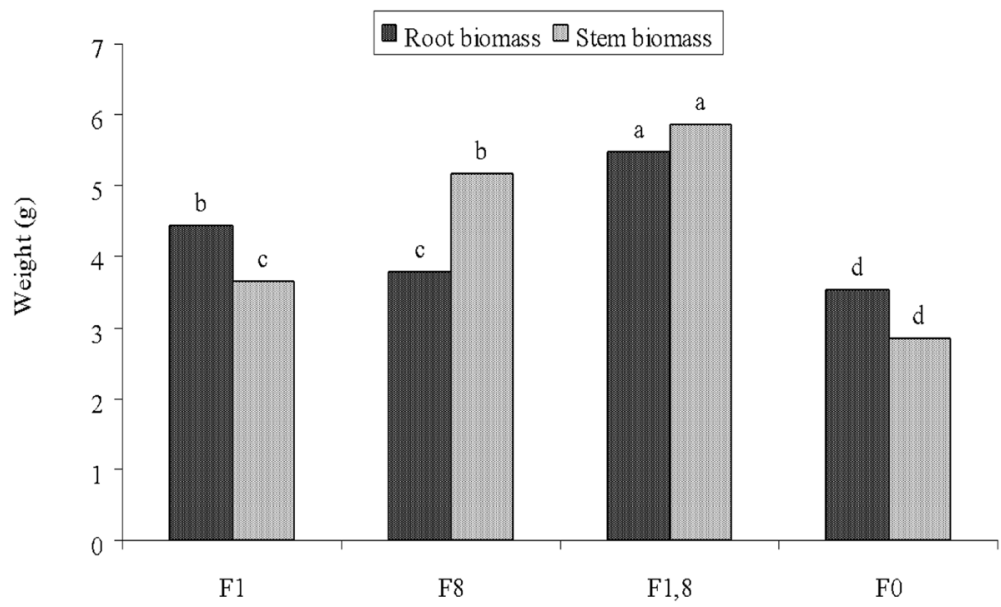

Fig. 2 Root and shoot biomasses of the treated samples. F1: Festuca with B. licheniformis ATHE9, F8: Festuca with B. mojavensis ATHE13, F1,8: Festuca with both bacteria $(F 1,8)$ and FO: Festuca without inoculations (control), Means with different letters $(a-d)$ are significantly different at $5 \%$ level 
plant to some degree in order for the plant to invest more energy into producing biomass.

\section{The PAHs concentration of treated soils}

The concentration of PAHs, 2-3rings (Light) and 4-6 rings (Heavy), in soil under different treatments after 3 months of bioremediation (rhizoremediation) are presented in Table 2. According to the results, there were some decreases in the PAHs concentration of control treatment (F0) in comparing with untreated soil that is related to the effect of Festuca by means of phytoremediation. The concentrations of hydrocarbons in the rhizosphere of treated soils significantly $(\mathrm{p}<0.05)$ decreased compared with the initial soil PAH concentrations and also in comparison with F0 significantly. In treatment $\mathrm{F}_{1,8}$, the residual levels of benzo[a] anthracene, benzo[ghi]perylene, chrysene and dibenzo[a,h]anthracene were lower than other treatments (more than 95\% degradation). The reduction of such PAHs concentration in the $\mathrm{F}_{1,8}$ treatment can be related to the synergistic effect of rhizobacteria (B.mojavensis and B.licheniformis) and plant in remediation of polluted soil which is known as rhizoremediation. Rhizoremediation application in crude oil contaminated soil has been confirmed as a proper and useful option to the cleanup of petroleum hydrocarbon in the contaminated environments [35]. In this synergistic process, bacteria are the main contributors to the degradation process. Plants release enzymes, amino acids, sugars and low molecular weight carbohydrates into the soil ecosystem that can increase the microbial activity and support the degradation of xenobiotic substances along with absorbing and accumulating or translocating the xenobiotics to the shoot, root or other parts of it [36]. Andria et al. [37] showed that plants inoculated with the endophyte were better able to grow in the presence of diesel. Higher expression of alkB genes suggesting a more efficient degradation of the pollutant was observed in their study [37].

The concentration decrease of 2- and 3- ring hydrocarbons in the rhizosphere were higher than heavier hydrocarbons in all treatments (e.g. $95.8 \%$ vs. $75,9 \%$ in $\mathrm{F}_{8}$ treatment) (Fig. 3). Heavy hydrocarbons were less exposed to microorganisms due to their lower solubility in an aqueous phase and higher adsorption on soil surfaces; as a result, their degradation is also lower. Haritash and Kaushik [10] stated that the presence of light oils instead heavy ones can increase the bioavailability of PAHs [10]. Soleimani et al. [12] reported the lowest degradation degree of benzo (ghi) perylene (a 6-ring PAH) and concluded that high-molecularweight PAHs do not easily serve as a carbon and energy source for microbial populations during degradation. They also stated that benzo (ghi) perylene could be removed in the presence of plant root exudates through the cometabolism mechanism [12].

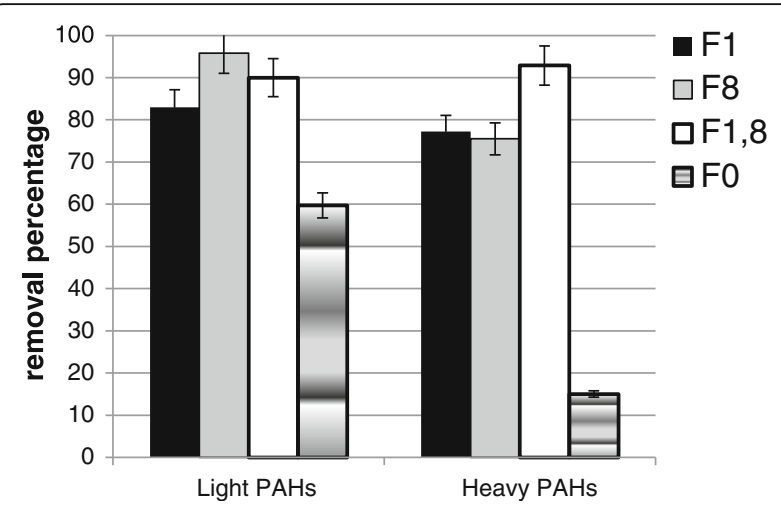

Fig. 3 The removal percentage of polycyclic aromatic hydrocarbons in the treated soil. F1: Festuca with B. licheniformis ATHE9, F8: Festuca with B. mojavensis ATHE13, F1,8: Festuca with both bacteria (F1,8) and FO: Festuca without inoculations (control)

Also, results showed that in treatments of Festuca inoculated with bacteria $\left(\mathrm{F}_{1}, \mathrm{~F}_{8}, \mathrm{~F}_{1.8}\right)$ the removal percentages of PAHs were significantly $(\mathrm{p}<0.05)$ more than Festuca without inoculation $\left(\mathrm{F}_{0}\right)$. Given these findings, it can be asserted that B. mojavensis and B. licheniformis have the potential for improving the conditions for remediation. The different degrading behavior of bacteria toward the types of hydrocarbons (light or heavy) can be attributed to the unique properties of each bacterium. Each bacterium acts uniquely in its degradation of certain hydrocarbons based on its specific enzyme system [27]. According to results of the present study, it can be asserted that the mechanism of bio and phytoremediation (rhizoremediation), which involves the plant and its dependent microbial activities in the rhizosphere, is greatly capable of removing PAHs from the soil. In such plant-bacteria partnership, plant supplies the bacteria with a special carbon source that stimulates them to degrade organic contaminants in the soil. In response, bacteria can support the plant to conquer contaminatedinduced stress responses, and improve plant growth and development. Additionally, plants get benefits from the bacteria with hydrocarbon-degradation ability, leading to enhanced hydrocarbon mineralization and lowering of both phytotoxicity and evapotranspiration of volatile hydrocarbons $[38,39]$ and improved the efficiency of phytoremediation [40]. Su and $\mathrm{Zhu}$ [22] also showed the relative contributions of plant uptake and plantpromoted rhizosphere microbial biodegradation of PAHs in a different environment [22].

\section{Conclusion}

Rhizoremediation process is an appropriate method for eliminating PAHs from the soil. In the present study, Festuca was inoculated with isolates of $B$. licheniformis ATHE9 and B. mojavensis ATHE13 which displayed a positive effect on PAHs dissipation. This can be a smart 
solution to combine the advantages of microbe-plant symbiosis within the plant rhizosphere into an effective cleanup technology with high performance. This method may be a promising strategy to remediate more contaminated sites along with the sustainable production of nonfood crops for biomass and biofuel production. Therefore, it may become attractive in developing countries because not expensive and requires little management.

\section{Abbreviations}

BSM: Basal Salt Medium; CFU: Colony Forming Unit; EC: Electrical Conductivity; OM: Organic Matter; PAH: Polycyclic Aromatic Hydrocarbons; PCR: Polymerase Chain Reaction

\section{Acknowledgements}

The authors would like to thank Biotechnology research center, Isfahan, Khorasgan branch, Islamic Azad University for their kind support.

\section{Funding}

This paper was part of a Ph.D. thesis of the first author.

\section{Availability of data and materials}

The authors do not wish to share their data. All the necessary data have been mentioned in the paper. Please contact author for data requests.

\section{Authors' contributions}

AT and $\mathrm{MH}$ carried out the scientific design and proposed the idea of research, participated in analyzing the findings and drafted the paper. AT also designed the microbial experiments. AA participated as scientific consulter for analyzing the findings. SE carried out the implementation of experiments in laboratory and any other activity in field such as sampling and etc. All authors read and approved the final manuscript.

\section{Competing interests}

The authors declare that they have no competing interests.

\section{Consent for publication}

Not applicable.

\section{Ethics approval and consent to participate}

Not applicable.

\section{Publisher's Note}

Springer Nature remains neutral with regard to jurisdictional claims in published maps and institutional affiliations.

Received: 20 August 2016 Accepted: 30 May 2017

Published online: 17 June 2017

\section{References}

1. Lyons WC. Standard Hand book of petroleum and natural gas engineering, vol. 1 Chapter 2. 2nd ed. Houston: Gulf Publishing Co; 2004.

2. Han MJ, Choi HT, Song HG. Degradation of phenanthrene by Trametes versicolor and its laccase. J Microbiol. 2004:42(2):94-8.

3. Dudhagara DR, Rajpara RK, Bhatt JK, Gosai HB, Sachaniya BK, Dave BP. Distribution, sources and ecological risk assessment of PAHs in historically contaminated surface sediments at Bhavnagar coast, Gujarat, India. Environ Pollut. 2016;213:338-46.

4. Kalantary RR, Mohseni-Bandpi A, Esrafili A, Nasseri S, Ashmagh FR, Jorfi S, Ja'fari M. Effectiveness of biostimulation through nutrient content on the bioremediation of phenanthrene contaminated soil. J Environ Health Sci Eng. 2014;12(1):1.

5. Ravanipour M, Kalantary RR, Mohseni-Bandpi A, Esrafili A, Farzadkia M, Hashemi-Najafabadi S. Experimental design approach to the optimization of PAHs bioremediation from artificially contaminated soil: application of variables screening development. J Environ Health Sci Eng. 2015;13(1):1.

6. Banks K. In: Govindaraju RS, Schwab AP, Kulakow P, editors. Phytoremediation of hydrocarbon-contaminated soil. Boca Raton: Lewis Publishers; 2000.
7. Swaathy S, Kavitha V, Pravin AS, Mandal AB, Gnanamani A. Microbial surfactant mediated degradation of anthracene in aqueous phase by marine Bacillus licheniformis MTCC 5514. Biotechnol Reports. 2014;4:161-70.

8. Doyle E, Muckian L, Hickey AM, Clipson N. Microbial PAH degradation. Adv Appl Microbiol. 2008;65:27-66.

9. Liu SL, Cao ZH, Liu HE. Effect of ryegrass (Lolium multiflorum L.) growth on degradation of phenanthrene and enzyme activity in soil. Plant Soil Environ. 2013;59(6):247-53.

10. Haritash AK, Kaushik CP. Biodegradation aspects of poly aromatic hydrocarbons (PAHs). J Hazard Mater. 2009;169(1-3):1-15.

11. Amora-Lazcano E, Guerrero-Zuniga LA, Rodriguez-Tovar A, RodriguezDorantes A, Vasquez- Murrieta MS. Rhizospheric plant-microbe interactions that enhance the remediation of contaminated soils. Curr Res Technol Edu Topics Appl Microbiol Biotechnol. 2010;1:251-6.

12. Soleimani M, Afyuni M, Hajabbasi M, Nourbakhsh F, Sabzalian M, Christensen J. Phytoremediation of an aged petroleum contaminated soil using endophyte infected and non-infected grasses. Chemosphere. 2010;81(9):1084-90.

13. Hogg TJ, Heury JL. Comparison and extracts with the saturation extracts in estimating salinity in Saskatchewan soils. Can J Soil Sci. 1984;64:699-704.

14. Rhoades JD. Cation exchange capacity. In: Page AL, Miller RH, Keeney DR, editors. Methods of soil analysis. Part 2. Chemical and microbiological properties. Madison: American Society of Agronomy, Inc. Soil Science Society of America. Inc; 1982. p. 149-57.

15. Lee SH, Lee WS, Lee CH, Kim JG. Degradation of phenanthrene and pyrene in rhizosphere of grasses and legumes. J Hazard Mater. 2008;153(1-2):892-8

16. Darmawan R, Nakata H, Ohta H, Niidome T, Takikawa K. Isolation and Evaluation of PAH Degrading Bacteria. J Bioremed Biodeg. 2015;6(283):2.

17. Vos P, Garrity G, Jones D, Krieng NR, Ludwig W, Rainey FA. Bergey's Manual of Systematic Bacteriology. Volume 3: The Firmicutes. 2009; P: 20-128.

18. McPherson MJ, Moller SG. PCR (the Basic). New Yourk Oxford: Springer-Verlag Telos publisher; 2000. Chapter 3: Reagents and Instrumentation.

19. Esmaeili M, Heidarzadel A, Pirdashti $H$, Esmaeili F. Inhibitory activity of pure allelochemicals on barnyard grass (Echinochloa crus-galli L) seed and seedling parameters. Int Agr Crop Sci. 2012;4(6):274-9.

20. Hamdi H, Benzarti S, Manusadzianas L, Aoyama L, Jedidi N. Bioaugmentation and biostimulation effects on PAH dissipation and soil ecotoxicity under controlled conditions. Soil Biol Biochem. 2007;39:1926-35.

21. Cunliffe $M$, Kertesz MA. Effect of Sphingobium yanoikuyae B1 inoculation on bacterial community dynamics and polycyclic aromatic hydrocarbon degradation in aged and freshly PAH- contaminated soils. Environ Pollut. 2006;144(1):228-37.

22. Su YH, Zhu YG. Uptake of selected PAHs from contaminated soils by rice seedling (Oryza sativa) and influence of rhizosphere on PAH distribution. Environ Pollut. 2008;155(2):359-65.

23. Yu YL, Chen YX, Luo YM, Pan XD, He YF, Wong MH. Rapid degradation of butachlor in wheat rhizosphere soil. Chemosphere. 2003;50:771-4.

24. Rodrigo S, Okeke C, Peralba M, Camargo O. Improved enrichment and isolation of polycyclic aromatic hydrocarbons $\mathrm{PAH}$-degrading microorganism in soil using anthracene as a model PAH. Curr Microbiol. 2009;58:628-34.

25. Riser-Roberts E. Remediation of petroleum contaminated soils: biological, physical and chemical processes. Boca Raton: Lewis Publishers; 1998.

26. Afzal M, Yousaf S, Reichenauer TG, Kuffner M, Sessitsch A. Soil type affects plant colonization, activity and catabolic gene expression of inoculated bacterial strains during phytoremediation of diesel. J Hazard Mater. 2011;186(2-3):1568-75.

27. Lease CWM. Biodegradation of high molecular weight polycyclic aromatic hydrocarbons in soils by defined bacterial and fungal co-cultures. South Australia: Theses for degree of PhD. Dissertation, University of South Australia Adelaide; 2004.

28. Peijnenburg WJGM. Fate of Contaminants in Soil". In: Doelman P, Eijsackers $H$, editors. Vital soil. Function, value and properties. Amsterdam: Elsevier; 2004. p. $245-80$

29. Adam G, Duncan $H$. Influence of diesel fuel on seed germination. Environ Pollut. 2002;120(2):363-70.

30. Jalilzadeh Yengejeh R, Sekhavatjou MS, Maktabi P, Arbab Soleimani N, Khadivi S, Pourjafarian V. The biodegradation of crude oil by Bacillus subtilis isolated from contaminated soil in hot weather areas. Int J Env Res. 2014;8(2):509-14.

31. Shahidi Rizi M, Akhavan Sepahi A, Tabatabaee MS. Crude oil biodegradation by a soil indigenous Bacillus sp. isolated from Lavan Island. Biorem J. 2012; 16(4):218-24.

32. Gonz'alez S, Capozucca E, Tigierm A, Milrad R, Agostini E. Phytoremediation of phenol from wastewater, by peroxidases of tomato hairy root cultures. Enzym MicrobTechnol. 2006;39:647-53. 
33. Smith MJ, Flowers TH, Duncan HJ, Alder J. Effect of polycyclic aromatic hydrocarbons on germination and subsequent growth of grasses and Legumes in Freshly contaminated soil and soil with aged PAHs residues. Environ Pollut. 2006;141(3):519-25.

34. Besalatpour A, Khoshgoftarmanesh AH, Hajabbasi MA, Afyuni M. Germination and growth of selected plants in a petroleum contaminated calcareous soil. Soil Sediment Contamin. 2008;17(6):665-76.

35. Ukaegbu-Obi KM, Mbakwem-Aniebo CC. The synergistic approach of plants and rhizobacteria in crude oil contaminated soil remediation. Eur J Environ Saf Sci. 2014;2(2):65-70.

36. Rohrbacher F, St-Arnaud M. Root Exudation: The Ecological Driver of Hydrocarbon Rhizoremediation. Agronomy. 2016;6(1):19-24.

37. Andria V, Reichenauer TG, Sessitsch A. Expression of alkane monooxygenase (alkB) genes by plant-associated bacteria in the rhizosphere and endosphere of Italian ryegrass (Lolium multiflorum L.) grown in diesel contaminated soil. Environ Pollut. 2009;157(12):3347-50.

38. Khan $\mathrm{S}$, Afzal M, labal $\mathrm{S}$, Khan QM. Plant-bacteria partnerships for the remediation of hydrocarbon contaminated soils. Chemosphere. 2013;90: 1317-32.

39. Khan S, Afzal M, lqbal S, Mirza MS, Khan QM. Inoculum pretreatment affects bacterial survival, activity and catabolic gene expression during phytoremediation of diesel contaminated soil. Chemosphere. 2013:91:663-8.

40. Weyens N, van der Lelie D, Taghavi S, Newman L, Vangronsveld J. Exploiting plant-microbe partnerships to improve biomass production and remediation Trends Biotechnol. 2009;27(10):591-8.

\section{Submit your next manuscript to BioMed Central} and we will help you at every step:

- We accept pre-submission inquiries

- Our selector tool helps you to find the most relevant journal

- We provide round the clock customer support

- Convenient online submission

- Thorough peer review

- Inclusion in PubMed and all major indexing services

- Maximum visibility for your research

Submit your manuscript at www.biomedcentral.com/submit 